\title{
Potenciál muzejní instituce v oblasti vědy a výzkumu na př́kladu Národního muzea
}

Nina Milotová, Jiří Frank

1 Podle ustanovení §2 odst. 3 zákona č. 122/2000 Sb., o ochraně sbírek muzejní povahy a o změně některých dalších zákonů, ve znění pozdèjších predpisü, je muzeem „instituce, která získává a shromažd'uje přirodniny a lidské výtvory pro vědecké a studijní účely, zkoumá prostředí, z něhož jsou prírodniny a lidské výtvory získávány, z vybraných prírodnin a lidských výtvorů vytvárí sbírky, které trvale uchovává, eviduje a odborně zpracovává, umož-

ňuje zpưsobem zaručujícím rovný prístup všem bez rozdílu jejich využivání a zpřistupňování $[\ldots]^{\prime \prime}$.

2 Citováno dle SKLENÁR, Karel. Obraz vlasti. Přiběh Národního muzea. Praha - Litomyšl: Ladislav Horáček - Paseka, 2001, s. 58.

3 Na uvedené deficity upozornil již před padesáti lety ve své průkopnické práci Jiří Neustupný. Viz NEUSTUPNÝ, Jiří.

Muzeum a věda. Muzejní práce, sv. 13. Praha: Národní muzeum, 1968.

4 Sledované téma tak může snadno sklouzávat k uchopení problematiky jako „pouhému" zpracování dějin a současného stavu jednotlivých, $v$ muzeu pěstovaných vědních oborů. Nabízí se zde paralela s problematičností sepsání dějin Národního muzea, jehož neustále se objevující potenciální slabinou je omezení na hromadění faktů z dějin jednotlivých muzejních oddělení. $K$ tomu WOITSCHOVÁ, Klára a JŮN, Libor. Národní muzeum jako historiografické téma. Casopis Národního muzea. Řada historická, 2015, roč. 184 , č. 1-2, s. 88.

Mgr. Nina Milotová, Ph.D.

Národní muzeum nina_milotova@nm.cz

RNDr. Jiří Frank, Ph.D. Národní muzeum jiri_frank@nm.cz

\section{The Potential of a Museum Institution in the Area of Science and Research on the Example of the National Museum}

Abstract: There is no doubt that science and research represent an elementary part of work of museum institutions. This fact was already stated by founder of the National museum, Count Kaspar Maria Stenberk (1761-1838), who said that only the scientific elaboration of museum collections increases their value for the society. Science and research are integral part of the complex of museum activities, but even though there is quite low awareness about the aspects, parameters, conditions and potential of museums research, especially in the Czech Republic. This fact is particularly visible in context of museum institutions ranking amongst other scientific organisations, where the purely scientific organisations have a prejudice against the museum research institutions even when the rating numbers talk differently. Museums in this context are mostly visible as content providers and rarely as a tools but almost never as legitimate scientific bodies, even when they have official status of research institutions. Other view is that of general public which mostly see the museums as source and tool for entertainment or education. The aim of this article is to demonstrate great potential of the museum institutions on the field of science and research and also open a discussion from the critical point of view from the side of the museum institutions themselves.

Keywords: Science and Research in Museum, Museum Legislation and Policies, Museum Collections, Research Disciplines, Museum Workers, Research Funding

\section{Úvod}

T ědecko-výzkumná činnost náleží bezpochyby $\mathrm{k}$ důležitým náplním činnosti muzejních institucí. ${ }^{1}$ Zmiňme na tomto místě slova ",otce zakladatele" Národního muzea hraběte Kašpara Marii Šternberka (1761-1838), dle kterých teprve vědecké zpracování sbírek přináší jejich skutečné zhodnocení pro společnost: „Největší sbirky, podobně jako nahromaděné tuny zlata, jsou mrtoými poklady, které nestoji ani za zmínku, pokud se jich náležitě neužíá ku prospěchu věd, $k$ dobru lidstva. "2 Přestože je věda základní součástí širokého spektra odborných aktivit realizovaných muzei, obecným otázkám spojeným s podobou, rozsahem a možnostmi muzejního výzkumu se nedostává odpovídající pozornosti. To stejné se týká problematiky postavení muzeí v hierarchii vědeckých institucí ${ }^{3}$, přičemž zvláštní pozornost si zde zaslouží muzea nesoucí zároveň status výzkumné organizace. Příčinou „opomíjení" výše zmíněné problematiky je jistě nejen pocitovaná "samozřejmost" existence vědy v prostředí těchto pamět'ových institucí, ale také nesnadno uchopitelná komplexnost muzejní vědecko-výzkumné práce přinášející s sebou celou řadu specifik. $^{4}$

Uvedená skutečnost má nepochybně vliv na vnímání muzeí zvenčí, a to jak ze strany 


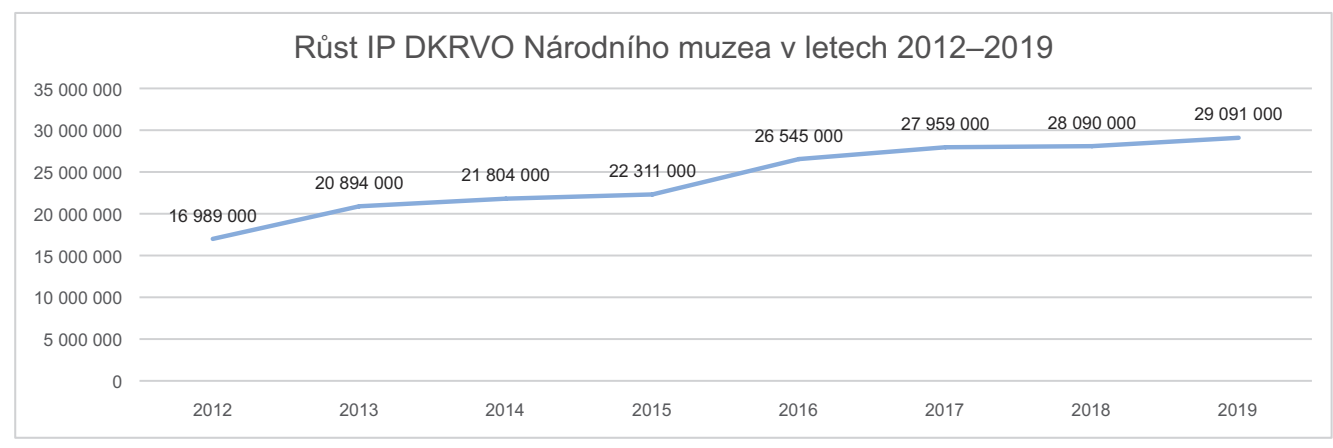

Obr. 1. Růst IP DKRVO Národního muzea v letech 2012-2019.

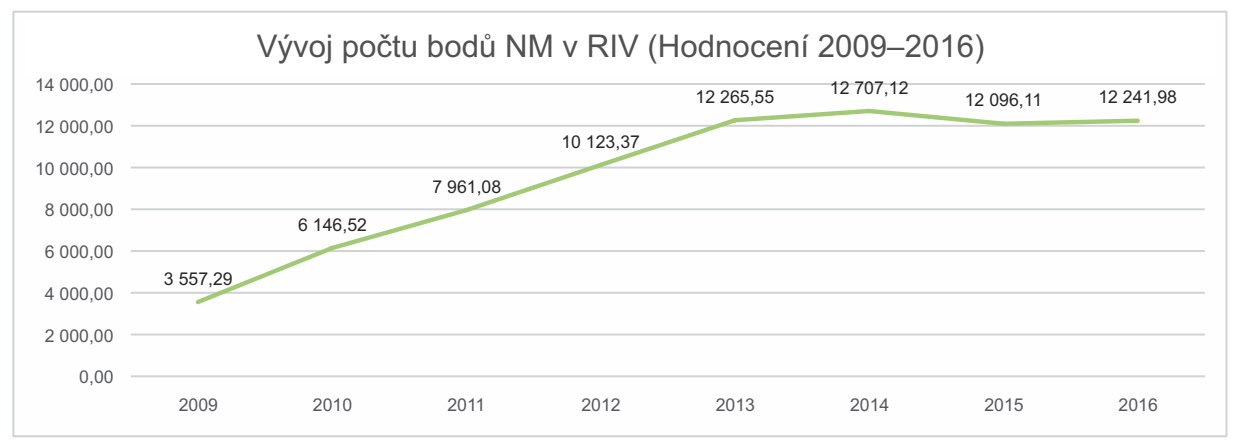

Obr. 2. Vývoj počtu bodů NM v RIV (Hodnocení 2009-2016).

laické veřejnosti, tak samotné vědecké komunity. Široká veřejnost vnímá především ostatní funkce muzejních institucí - výstavní, sbírkotvornou a vzdělávací. Pro mnohé $z$ návštěvníků může být dokonce překvapením, že za zdmi muzeí probíhá výzkum. Čistě výzkumné organizace poté často nedocení skutečný muzejní potenciál a výkon na poli vědy. S tím souvisí též nedostatečné povědomí v řadách vysokoškolských studentů (především humanitních oborů) o možnostech tamější pramenné základny (nejen archivního, ale též hmotného materiálu) pro výzkum a o podobě realizace vědy $\mathrm{v}$ muzeích obecně. ${ }^{5}$ Cílem předkládaného článku je poukázat na mnohdy opomíjený potenciál muzejní instituce v oblasti vědy (samozřejmě v závislosti na velikosti a zaměření konkrétního muzea) a otevřít tak diskusi spojenou s reflexí nastíněné problematiky ze strany samotných muzeí. Př́klad Národního muzea, příspěvkové organizace Ministerstva kultury, největší české muzejní a zároveň nejstarší souvisle působící vědecké instituce, může v této souvislosti nabíd- nout zajímavý vhled do barvitého spektra sledované problematiky. Dvousté výročí od založení instituce je navíc vhodnou příležitostí pro představení aktuálního postavení Národního muzea v oblasti vědy, u jejíž „,kolébky“ v př́ípadě řady v Čechách rozvíjejících se vědních oborů v minulosti samo stálo. ${ }^{6}$ Za mnohé $\mathrm{z}$ osobností vědeckého života 19. století spjatých s touto institucí jmenujme např. Františka Palackého (1798-1876), jenž se zde zasloužil mj. o posílení postavení humanitních oborů. $\mathrm{V}$ rámci př́rodovědných oborů, které stály u samotného základu vzniku muzea, to byli např́klad Kašpar Maria Šternberk, Antonín Frič či Jan Krejčí. ${ }^{7}$

\section{Muzeum jako pramenná základna výzkumu a jeho pracovníci}

Oficiální formální status výzkumné organizace získalo Národní muzeum v roce 2009. ${ }^{8}$ Z hlediska výkonu a aktivit v oblasti vědecké činnosti je Národní muzeum na přední pozici z 20 institucí resortu Ministerstva kultury vedených na příslušném
5 Zde je vhodné zmínit, že mnozí z pracovníků Národního muzea, věrni "duchu tradice" instituce, prednášejí na vysokých školách (mnozí jsou též vedoucími magisterských a disertačních prací). Také tímto způsobem se otevírají možnosti v oblasti vzájemné informovanosti a navázání kontaktů mezi univerzitním a muzejním prostředím.

$6 \mathrm{~K}$ historii jednotlivých muzejních oborů pěstovaných na půdě Národního muzea napr̆. SKALSKY, Gustav a kol. Národní museum 1818-1948. Praha: Orbis, 1949 či již citovaná publikace SKLENÁR̆, Karel. Obraz vlasti. Príběh Národního muzea. Praha - Litomyšl: Ladislav Horáček - Paseka, 2001. 7 U zrodu Národního muzea stály dary velkých soukromých sbirek predevším prírodovědeckého charakteru z majetku $v$ Čechách žijicích aristokratů. Mezi ně patřil např. také již zmiňovaný hrabě Kašpar Maria Šternberk. 
8 Od roku 2009 oficiálně zapsáno jako výzkumná organizace. $V$ ríjnu 2017 byla instituce zapsána na nový seznam výzkumných organizací, vedený od 1. července 2017 MŠMT (dríve v gesci Rady pro výzkum, vývoj a inovace).

[cit. 5. 11. 2019] Dostupné z: http://www.msmt.cz/vyzkum-avyvoj-2/narodni-muzeum

9 Seznam výzkumných organizací (MŠMT). [cit. 5. 11. 2019] Dostupné $z$ : http://www.msmt.cz/vyzkum-avyvoj-2/vyzkumne-organizace 10 Dle čl. IV odst. 2 Zřizovací listiny Národního muzea (Rozhodnutí ministryně kultury č. 43/2012 ze dne 20. prosince 2012) byla instituce zrízena za účelem „provádět základní výzkum, aplikovaný výzkum nebo experimentální vývoj týkající se sbírek a prostředí, z nějž jsou získávány sbírkové předměty a širitit výsledky výzkumu a vývoje prostřednictvím výuky, publikování, muzejních výstav a muzejních programů, metodiky nebo převodu technologii.". [cit. 5. 11. 2019] Dostupné z:

https://www.nm.cz/muzeum/onas/dulezite-dokumenty

11 Ta je konkrétně definována $v$ čl. IV odst. 1 Zřizovací listiny Národního muzea. Tamtéž.

V CES je aktuálně evidováno 38 podsbírek Národního muzea. [cit. 5. 11. 2019] Dostupné z: http://www.cesonline.cz/arlces/cs/index/

12 Zatímco prírodovědné obory jsou soustredèny v rámci Prírodovědeckého muzea (to je zároveň výrazně nejsilnější složkou z hlediska počtu vykazovaných výsledků), obory humanitní $\checkmark$ Historickém muzeu, Náprstkově muzeu asijských, afrických a amerických kultur, Českém muzeu hudby a $v$ Knihovně Národního muzea. Do aktivit v oblasti výzkumu se dále zapojují pracovníci Odboru náměstka

pro centrální sbírkotvornou a výstavní činnost a Ředitelství Národního muzea.

13 NEUSTUPNÝ, Jiř́: Otázky dnešního muzejnictví. Príspěvky k obecné a speciální museologii. Praha: Orbis, 1950, s. 61. aktuálním seznamu výzkumných organizací. ${ }^{9}$ Celkově za Českou republiku je na tomto seznamu vedeno 205 institucí zahrnujících vysoké školy, ústavy Akademie věd ČR, další veřejné výzkumné instituce, příspěvkové organizace či právnické osoby zapsané v obchodním rejstř́ku. Mimo resort Ministerstva kultury se zde nachází dalších 7 muzeí / galerií, spadajících pod Hlavní město Praha, Plzeňský kraj, Královéhradecký kraj, Zlínský kraj, Ministerstvo školství, mládeže a tělovýchovy a Ministerstvo zemědělství.

Dle Zřizovací listiny Národního muzea je předmětem hlavní činnosti této instituce realizace základního a aplikovaného výzkumu. ${ }^{10}$ Širokou pramennou základnu pro výzkum představují $\mathrm{v}$ muzejním prostředí sbírky, jež vědecky zkoumají nejen pracovníci muzea, ale také badatelé a vědci $\mathrm{z}$ dalších institucí (čistě vědecké instituce mají vlastní sbírkovou/obsahovou základnu často podstatně menší nebo velmi úzce zaměřenou). $V$ prrípadě Národního muzea hraje výraznou roli nejen množství jím spravovaných sbírkových předmětů (více než 20 milionů), ale především vysoká diverzita sbírek samotných ${ }^{11}$, na něž jsou dále navázány související, v instituci zastoupené vědní obory (prrírodovědné a humanitní1 ${ }^{12}$, mající své zastoupení mj. ve dvou př́slušných sekcích vědeckého poradního orgánu instituce - Vědecké rady). Výzkum, založený na sbírkových fondech a prostředí, z něhož sbírkové předměty pocházejí, je poté vázán na odborné zpracování těchto sbírkových předmětů, často v podobě kritických katalogů sbírek. Důležitá je přitom skutečnost, že odborná a vědecká práce se sbírkami výrazným způsobem zvyšuje jejich hodnotu. „Vrcholným vědeckým zpracováním musejniho materiálu je jeho publikace."13 Vedle primárního zkoumání sbírek, které zároveň tvoří pramenné fondy vědních oborů, je nezbytná pozornost věnována také jejich ochraně (konzervaci, restaurování), prezentaci a nezbytnému efektivnímu zpřístupnění, jehož nástrojem jsou digitalizace sbírkových předmětů a dat. Uvedené činnosti vedou zpětně $\mathrm{k}$ poptávce po muzeu ze strany návštěvníků, odborné veřejnosti a dalších institucí.
Vědeckou činnost pamětové instituce je nezbytné vnímat $\mathrm{v}$ kontextu všech jejích dalších aktivit - výstavní činnosti (expozice, krátkodobé výstavy - s potenciálem širokého dosahu), popularizační činnosti (přednášky, popularizační publikace), vzdělávání (edukační a lektorské programy). Náplň práce zaměstnanců Národního muzea, kteř́ se podílejí na výzkumu, je tak $\mathrm{v}$ různé míře realizována ve třech oblastech: odborné (správa sbírky), vědecko-výzkumné (vědecké zhodnocení sbírek) a popularizační (výstavy, popularizační články, přednášky apod.). Na vědecko-výzkumné činnosti instituce se proto podílejí nejen výzkumní pracovníci, ale také kurátoři, dokumentátoři, restaurátoři, konzervátoři, knihovníci a archivári. Rozsah v muzeu zastoupených profesí a oborů (nesoucí s sebou zároveň odpovídající požadavky na kvalitní odborné personální zastoupení) dokládá šîře vědních oborů/podoborů, v jejichž rámci pracovníci instituce vyvíjejí svoji vědecko-výzkumnou činnost.

Z celkového počtu 6 vědních oblastí dle struktury oborů $\mathrm{OECD}^{14}$ spadají publikační výstupy pracovníků Národního muzea především do dvou $\mathrm{z}$ nich. $V$ rámci první vědní oblasti 1. Natural Sciences se jedná především o obory/podobory: -1.5 Earth and related environmental sciences (zahrnující zejména paleontologii, mineralogii a geologii); - 1.6 Biological sciences (zahrnující široké spektrum od botaniky, mykologie, zoologie, včetně většiny podoborů, jako jsou entomologie a ornitologie, až po ekologii a genetiku). V rámci druhé vědní oblasti 6. Humanities and the Arts jsou především zastoupeny obory/podobory: - 6.1 History and Archaeology (zahrnující široké spektrum historie a archeologie); - 6.4 Arts (Arts, History of arts, Performing arts, Music) (zahrnující například historii divadla, umění, folkloru či obor muzikologie). Vedle zmíněných však nalezneme výstupy také ve dvou dalších vědních oblastech. Jsou jimi výsledky (nejen) aplikovaného výzkumu v oblasti 2. Engineering and Technology. Zde se jedná o obory/podobory - 2.2 Electrical engineering, Electronic engineering, Information engineering (Electrical and electronic engineering, Automation and control systems); - 2.5 
Materials engineering (Textiles, coating and films). Další výsledky jsou publikovány se zaměřením 5. Social Sciences - obory/podobory - 5.4 Sociology (Anthropology, ethnology; Social topics); - 5.8 Media and communications (zahrnující informační a knihovní vědy). Z výše uvedeného je patrné, že instituce tvoří ideální prostor pro širokou interdisciplinární spolupráci.

\section{Zdroje financování výzkumu a jejich vliv na rozvoj vědecko-výzkumné činnosti muzea}

Základním zdrojem tvořícím stavební kámen pro zajištění kvalitních podmínek rozvoje vědy v Národním muzeu je institucionální podpora pro dlouhodobý koncepční rozvoj výzkumné organizace (IP DKRVO) ${ }^{15}$. Tyto finanční prostředky jsou využívány v rámci investic (primárně pořízení a údržba přístrojového a laboratorního vybavení), neinvestičních nákladů (cestovné - terénní výzkum, badatelská činnost ve sbírkách tuzemských a zahraničních institucí, účast na konferencích a sympoziích; materiál - obalové materiály, chemikálie, materiály využívané v laboratořích; ostatní služby - např. tisk publikací) a mzdových nákladů. Na IP DKRVO se každoročně podílí cca 300 pracovníků Národního muzea, ${ }^{16}$ mzdová alokace $v$ rámci IP DKRVO je řešena nadtarifní složkou platu jako motivační prvek hodnotící primárně výsledky a činnost v oblasti vědy a výzkumu podle interních metodik hodnocení (odděleně pro přírodovědné a společenskovědní obory).

Většina výsledků Národního muzea vykazovaných do Rejstříku informací o výsledcích (dále jen RIV) ${ }^{17}$ vzniká v rámci institucionální podpory, přičemž hodnocení výsledků v RIV zároveň ovlivňuje výši této podpory (viz obr. 1-3). Za předcházející období 2013-2017 instituce vykázala celkem 1363 výstupů, z toho 973 v rámci IP DKRVO. ${ }^{18}$ Rostoucí kvalita výsledků pracovníků muzea ${ }^{19}$ (např. v rámci Hodnocení $2016^{20}$ se instituce umístila - z pohledu celků - na 53. místě z tehdy vedených 241 výzkumných organizací) se odráží v každoročně se zvyšující výši institucionální podpory. Zatímco v roce 2012 se jednalo o 16989000 Kč, na rok 2019 připadá již částka 29091000 Kč (dle dlouhodobé koncepce na léta 2019-2023). ${ }^{21} \mathrm{~V}$ roce 2018 bylo v rámci IP DKRVO realizováno celkem 60 výzkumných cílů, jejichž výsledky prezentovali pracovníci formou 147 příspěvků na konferencích ( $\mathrm{z}$ toho 77 zahraničních).

Přestože je možné považovat institucionální podporu za "hnací motor" výzkumu v instituci, nezanedbatelnou položku v oblasti financování vědy tvoří také další typy financování. Vedle účelové podpory - projektů základního výzkumu Grantové agentury České republiky (dále jen GA ČR), projektů Programu aplikovaného výzkumu a vývoje národní a kulturní identity (dále jen NAKI) ${ }^{22}$, mezinárodních projektů a operačních programů - jsou to provozní rozpočet $^{23}$ instituce a smluvní podpora. Konkurenceschopnost instituce nejen v oblasti kvality a kvantity výzkumu a publikovaných výstupů výrazným způsobem stimuluje její spolupráce s dalšími institucemi na národní i mezinárodní úrovni (mezinárodní smlouvy o spolupráci týkající se terénního výzkumu a výměny zkušeností a prezentace vědecko-výzkumných výsledků formou výstav, mezinárodní smlouvy v rámci projektů vědy a výzkumu, účast instituce v konsorciích ${ }^{24}$ a asociacích, mezinárodní spolupráce - partnerství bez smlouvy). Spolupráce se zahraničními vědci a výzkumnými týmy také přináší lepší možnosti publikování v prestižních zahraničních impaktovaných časopisech.

Zatímco základní výzkum je realizován primárně v rámci IP DKRVO ${ }^{25}$ a projektů GAČR ${ }^{26}$, výzkum aplikovaný je soustředěn $\mathrm{v}$ rámci projektů $\mathrm{NAKI}^{27}$. Účelová podpora má pro instituci výrazný efekt v podobě rostoucích zkušeností pracovníků nejen ve vědě samotné, ale zároveň v oblasti získávání projektů z různých dotačních programů, v rozvoji aplikovaného výzkumu a ve zvyšující se technologické vybavenosti pracovišt'. Zejména řešení projektů NAKI s sebou nese vznik výsledků aplikovaného výzkumu - certifikovaných metodik, specializovaných map s odborným obsahem, funkčních vzorků atd. Je však nutné zdůraznit, že rok uplatnění aplikovaných
14 Jedná se o 1. Natural Sciences, 2. Engineering and Technology, 3. Medical and Health Sciences, 4. Agricultural and Veterinary Sciences, 5. Social Sciences, 6. Humanities and the Arts. Viz Struktura oborü OECD (Frascati manual) - prevodník 17+. [cit. 5. 11. 2019]

Dostupné z: https://www.vyzkum.cz/FrontClanek.aspx?idsekce $=799796$

15 IP DKRVO čerpá Národní muzeum prostřednictvím svého poskytovatele, Ministerstva kultury, od roku 2012. $\checkmark$ předcházejícím období byla realizována prostřednictvím tzv. výzkumných záměrů (v letech 2005-2011 jimi byly: Vědecké zhodnocení a rozširrování prírodovědeckého sbírkového fondu Národního muzea

(MK00002327201) a Osobnosti české vědy a kultury

(MK00002327202). Viz Informační systém výzkumu, vývoje a inovací (dále jen IS VaVal) Centrální evidence záměrů (CEZ). [cit. 5. 11. 2019] Dostupné z: https://www.rvvi.cz/cez

16 Jedná se o kmenové zaměstnance a osoby na DPP.

17 Povinnost vykázání údajů stanovuje př́jemci podpory \$31 odst. 3 zákona č. 130/2002 Sb., o podpoře výzkumu, experimentálního vývoje a inovací. Postup príjemce při predání údajů dále rozvádí §7 nařízení vlády ze dne 19. ríjna 2009, o informačním systému výzkumu, experimentálního vývoje a inovací. Od roku 2017 používá Národní muzeum pro sběr záznamů o těchto výsledcích, jejich správu a vykázání do RIV systém OBD (Osobní bibliografická databáze).

18 Viz údaje $v$ IS VaVal - RIV. [cit. 5. 11. 2019] Dostupné z: https://www.rvvi.cz/riv

19 Objem vědecko-výzkumných aktivit si vyžaduje nezbytný systematický prístup ke koncepci vědecké práce. Administrace výsledků probíhá v Národním muzeu po linii: pracovník - oddělení - odborná složka - oddělení vědeckého tajemníka (provádí koncepční a realizační podporu v oblasti vědy) - Odbor výzkumu a vývoje Ministerstva kultury-RVVI. 
20 Hodnocení výsledků výzkumných organizací v roce 2016: [cit. 5. 11. 2019] Dostupné $z$ : https://www.vyzkum.cz/FrontClanek.aspx?idsekce $=799261$ 21 Dlouhodobá koncepce rozvoje výzkumné organizace Národní muzeum na léta 20192023 (2018). [cit. 5. 11. 2019] Dostupné z: https://www.mkcr.cz/vysledkyvstupniho-hodnoceni-vyzkumnych-organizaci-mk-na-zakladepeer-review-hodnoceni-dlouho dobe-koncepce-rozvoje-vo-naleta-2019-2023-1976.html 22 Viz IS VaVal - Centrální evidence projektů (CEP). [cit. 5. 11. 2019] Dostupné z: https://www.rvvi.cz/cep

$23 Z$ něho jsou financovány např. interní vědecké granty (od roku 2007), odborné stáže pro pracovníky apod.

24 Významný prínos konsorciální spolupráce je možné spatrovat např. v kontextuálním propojení vědeckých databází a rozšiření možností využití výsledků výzkumu a dat.

25 Do této oblasti spadaji také od roku 2015 udělované interní mezioborové granty.

$26 \mathrm{~V}$ roce 2018 řeši instituce 10 projektů GA ČR s celkovým rozpočtem 7773000 Kč.

27 V roce 2018 se jedná

o 7 projektů NAKI s rozpočtem ve výši 14950000 Kč.

$28 \mathrm{Tj}$. sběr do RIV realizovaný $v$ roce 2016, jenž se týkal primárně výsledků uplatněných roku 2015.

29 Definice druhů výsledkü,

Samostatná př́loha č. 4 Metodiky hodnocení výzkumných organizací a programů účelové podpory výzkumu, vývoje a inovací schválené usnesením vlády dne 8. února 2017 č. 107. Tato aktualizovaná Definice je platná od 1. 1. 2018.

30 V rámci RIV18 vykázalo Národní muzeum z celkového počtu 310 výsledků (z nich 161 publikovaných $v$ angličtině) 109 přírodovědeckých článků publikovaných $v$ časopisech indexovaných $v$ databázi Web of Science (Jimp), naopak ze 14 vykázaných odborných knih spadalo 12 do humanitních oborů.

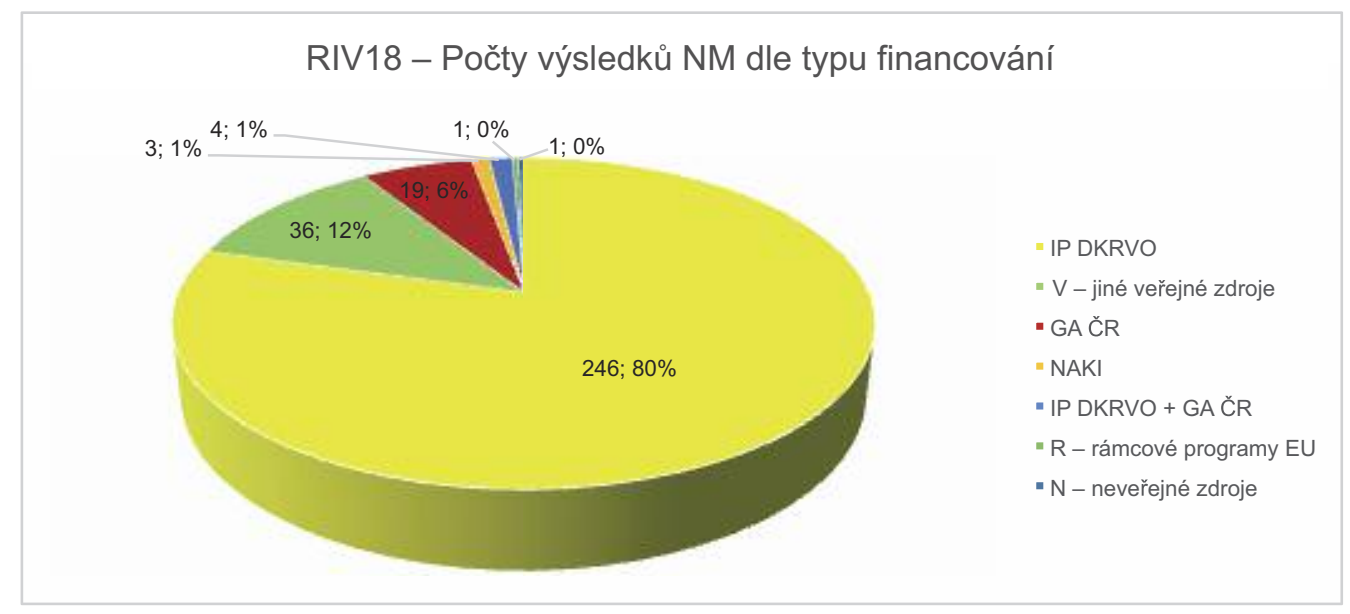

Obr. 3.: RIV18 - Počty výsledků NM dle typu financování.

výsledků NAKI je úzce vázán na stadium, v němž se př́islušný projekt nachází (resp. končí). Názorným př́kladem je tak sběr do RIV16 ${ }^{28}$, který skokově přinesl celkem 60 výstupů realizovaných $\mathrm{v}$ rámci NAKI (tj. $20 \%$ všech tehdy vykazovaných výsledků), mezi nimi taktéž mnohé aplikované výsledky (viz obr. 4). Důvodem této skutečnosti bylo 5 projektů NAKI končících $\mathrm{v}$ předcházejícím roce 2015. Je důležité zmínit, že zkušenosti s realizací aplikovaného výzkumu v rámci NAKI se již začínají promítat také do řešení a výstupů výzkumných cílů IP DKRVO, kde staví na již realizovaném základním výzkumu.

Významným faktorem ovlivňujícím hodnocení Národního muzea jako výzkumné organizace je skutečnost, že tato instituce figuruje $\mathrm{v}$ procesu hodnocení, jenž spadá do gesce Rady pro výzkum, vývoj a inovace, jako jeden celek, bez přihlédnutí k internímu organizačnímu/oborovému dělení (naopak vysoké školy jsou hodnoceny na úrovni fakult, Akademie věd ČR na úrovni jednotlivých ústavů). Výstupy tak vhodným způsobem pokrývají široké spektrum hodnotitelných druhů výsledků dle aktuálně platné Definice druhů výsledkư ${ }^{29}$ (např. impaktované články publikované $\mathrm{v}$ rámci přírodovědeckých oborů vs. odborné knihy, jež jsou především doménou společenskovědních oborů $)^{30}$. Tato skutečnost se názorně projevila při prvním hodnocení Národního muzea dle Metodiky $17+{ }^{31}$, a to v rámci Modulu 1 - Kva- lita vybraných výsledkư ${ }^{32}$. Instituce tak mohla nominovat rozličné druhy výstupů odpovídající svému oborovému zaměření. ${ }^{33}$ $Z$ celkového počtu 13 výsledků byly navíc na pětiškálové stupnici oceněny dva nejvyšší známkou 1 - Výsledek na špičkové úrovni (world-leading) ${ }^{34}$. V oborové skupině 6. Humanities and the Arts tak Národní muzeum získalo dva ze šesti nejlépe hodnocených výstupů. ${ }^{35}$

\section{Věda v muzeu v kontextu změn v oblasti hodnocení výzkumu a vývoje v ČR}

Není pochyb o tom, že muzeum, jež zároveň plní funkci výzkumné organizace, je v oblasti vědecko-výzkumné činnosti výrazně ovlivňováno nastavením systému hodnocení výzkumu a vývoje v ČR. Je tak konfrontováno s nezbytností reflexe vývoje $\mathrm{v}$ dané oblasti a schopnostmi reakce na nově přicházející změny a výzvy. $\mathrm{V}$ současné době prochází systém hodnocení výzkumných organizací v ČR dynamickým obdobím nastartovaným novou Metodikou hodnocení výzkumných organizací a hodnocení programů účelové podpory výzkumu, vývoje a inovací" (dále jen Metodika $17+)^{36}$, jež nahrazuje starší Metodiku hodnocení výsledků výzkumných organizací a hodnocení výsledků ukončených programů (platná pro léta 2013 až 2016) ${ }^{37}$. Cílem je nově hodnotit nejen kvantitu (dřívější „,kafemlejnek" zhodnocující instituci 


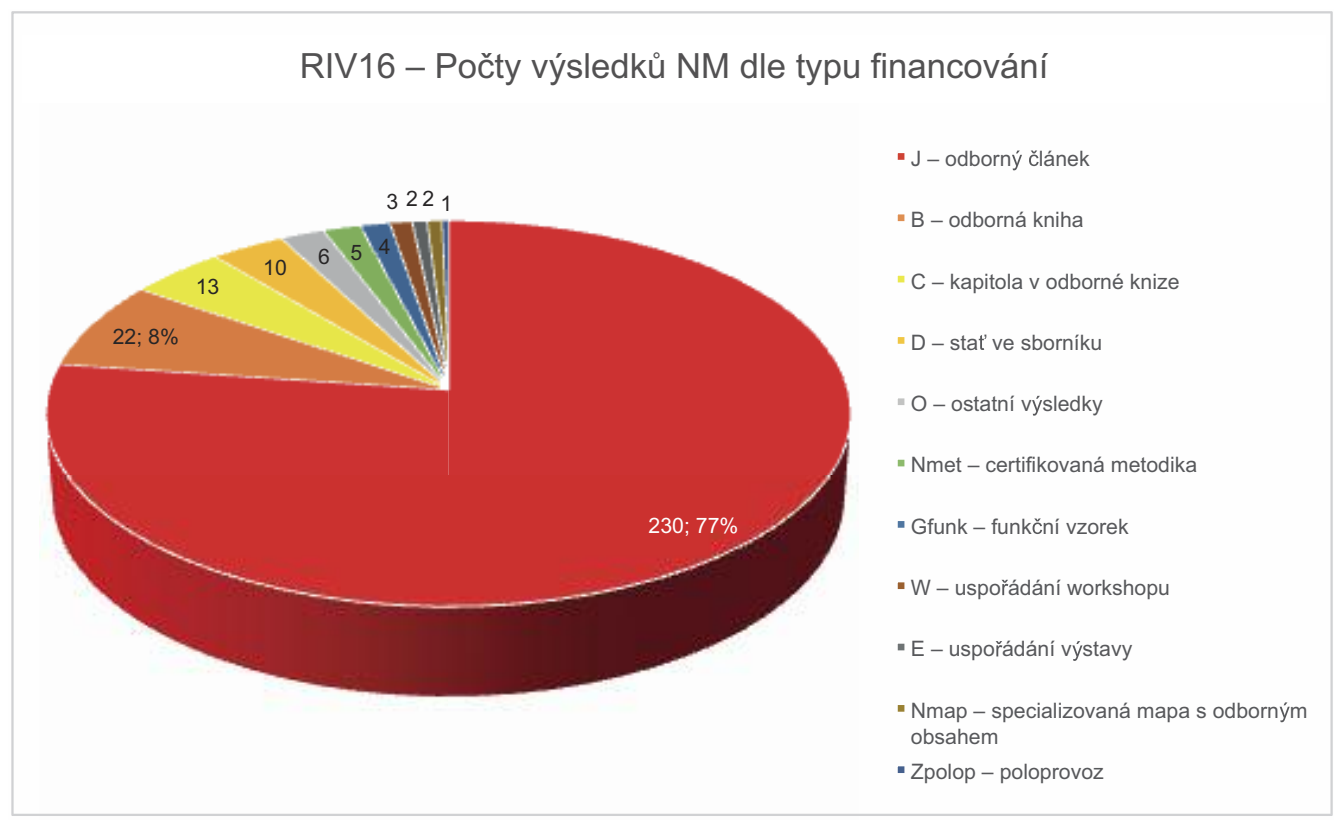

Obr. 4.: RIV16 - Počty výsledků NM dle druhů výsledků.

na základě přidělených bodů v RIV, jenž však znevýhodňoval společenskovědní a humanitní obory), ale také kvalitu výzkumu. Nový systém hodnocení ${ }^{38}$, jehož komplexní podobu a výsledný efekt prokáže až následující období (v letech 20172019 probíhá implementační fáze, od roku 2020 je plánováno pravidelné kompletní pětileté hodnocení výzkumných organizací), nabízí muzejní instituci s výrazným potenciálem v oblasti vědy vhodnější možnost zúročení výsledků její činnosti.

Nový systém hodnocení (5 modulů) výzkumných organizací počítá se zohledněním rozdílnosti poslání jednotlivých institucí (a také oborových specifik), výzkumné organizace dělí do tří segmentů - vysoké školy, ústavy AV ČR, resortní výzkumné organizace. Metodika přináší dále nový způsob hodnocení výsledků vykazovaných do RIV. Ty jsou děleny na tzv. bibliometrizovatelné39 (Modul 2 - Výkonnost výzkumu) a nebibliometrizovatelné výstupy $^{40}$ (již zmíněný Modul 1 - Kvalita vybraných výsledků). Na rozdíl od dřívějšího systému hodnocení, jenž ve výsledku „,redukoval“ vědecko-výzkumnou činnost instituce pouze na jednu z realizovaných oblastí (hodnocení zůstalo skryto široké spektrum dalších činností dotýkajících se vědy a výzkumu), budou nově sledovány také další aspekty. Zohledněna má být mezinárodní a národní spolupráce instituce, úspěšnost v získávání a realizaci projektů, stáže mladých vědeckých pracovníků v zahraničí, smluvní výzkum atd. Pozornost bude věnována též kvalitě řízení a vnitřních procesů výzkumných organizací a jejich koncepcím a strategiím ${ }^{41}$.

V součinnosti s implementací nové Metodiky 17+ proběhlo v roce 2018 hodnocení výzkumných organizací resortu Ministerstva kultury, jehož cílem bylo rozřadit příslušné instituce do čtyřstupňové škály (A - vynikající, B - velmi dobrá, C - průměrná, D - podprůměrná). Hodnocení probíhalo na základě předložení Dlouhodobé koncepce rozvoje výzkumné organizace na léta 2019-2023 ${ }^{42}$, jež zahrnovala nejen závazný plán výzkumu na uvedené období, ale také analýzu činnosti a výsledků za předcházejících pět let a strategie a vizi výzkumné organizace. Na základě zhodnocení předloženého dokumentu ${ }^{43}$ bylo Národní muzeum zařazeno do nejvyšší kategorie - „,A“, čímž si zajistilo mj. navýšení institucionální podpory garantované po celé nadcházející pětileté období
31 Viz Metodika hodnocení výzkumných organizací a hodnocení programů účelové podpory výzkumu, vývoje a inovací, schválená Usnesením vlády ČR ze dne 8. února 2017 č. 107. [cit. 5. 11. 2019] Dostupné z: https://www.vyzkum.cz/FrontClanek.aspx?idsekce $=799796$

$32 \mathrm{~V}$ tomto konkrétním prípadě však označen jako „Modul 1 - Hodnocení vybraných výsledků". Hodnocení vybraných výsledků nahradilo hodnocení excelentních výsledků v rámci Pilíře II dle Metodiky 2013-2016. V prvním roce hodnocení dle Metodiky 17+ probíhalo dle kritéria společenské relevance, celkem bylo hodnoceno cca 1500 výstupů uplatněných $v$ roce 2016.

33 Jednalo se o odborné monografie (7), certifikované metodiky (3), specializovanou mapu s odborným obsahem (1), funkční vzorek (1) a odborný článek (1).

34 Konkrétně se jednalo o publikace Afghanistan. Rescued Treasures of Buddhism a Bedrich Smetana. Korespondence I. (1840-1862). 4 výsledky byly následně ohodnoceny známkou 2 - Výsledek na vynikající úrovni (excellent).

35 Výsledky hodnocení jsou dostupné $z$ :

https://hodnoceni17.rvvi.cz/ww w/nebiblio [cit. 5. 11. 2019]. 36 Schválena usnesením vlády ČR ze dne 8. února 2017 č. 107. Zmíněná metodika má rámcový charakter. [cit. 5. 11. 2019] Dostupné z: https://www.vyzkum.cz/FrontClanek.aspx?idsekce $=799796$

37 Metodika schválena usnesením vlády ČR ze dne 19. června 2013 č. 475, ve znění usnesení vlády ze dne 16. dubna 2014 č. 250 a usnesení vlády ze dne 29. července 2015 č. 605.

[cit. 5. 11. 2019] Dostupné z: https://www.vyzkum.cz/FrontClanek.aspx?idsekce=799259 
38 Metodika 17+ počitá se třemi úrovněmi hodnocení: 1) na úrovni RVVI (hodnocení pro účely rízení a financování celého systému výzkumu, vývoje a inovací), 2) na úrovni poskytovatelů a 3) pro potřeby řízení výzkumné organizace. Hodnoceny tak budou nejen výstupy, ale také dopady a celkové výhledy rozvoje instituce. Ta bude zároveň hodnocena jak v národním, tak mezinárodním měřitku.

39 Výsledky druhu Jimp, Jsc, D publikované $v$ časopisech/publikacích indexovaných v databázích Web of Science a Scopus. Zde probíhá hodnocení na základě bibliometrických analýz.

40 Všechny ostatní druhy výsledků mimo uvedené Jimp, Jsc a D. Hodnocení vybraných nebibliometrizovatelných výstupu je založeno na hodnocení peer review.

$41 \mathrm{~V}$ tomto ohledu zastihla implementace nového systému hodnocení Národní muzeum připravené. Viz např. Směrnice GR̆ č. 10/2016 - Podmínky naplňování Koncepce rozvoje a podpory výzkumu a vývoje v Národním muzeu, včetně príloh; především Příloha č. 1 - Koncepce rozvoje a podpory výzkumu a vývoje v Národním muzeu 2016-2020.

[cit. 5. 11. 2019] Dostupné z: https://www.nm.cz/muzeum/onas/dulezite-dokumenty

42 Jednotlivé dokumenty jsou dostupné $z$ :

https://www.mkcr.cz/vysledkyvstupniho-hodnoceni-vyzkumnych-organizaci-mk-na-zakladepeer-review-hodnoceni-dlouho dobe-koncepce-rozvoje-vo-naleta-2019-2023-1976.html [cit. 5.

11. 2019].

43 Hodnocení proběhlo ve 3 etapách, přičemž závěrečnou etapu provedla prostrednictvím peer review Rada ministra kultury pro výzkum (RMKPV). (v této době bude realizováno 352 kontrolovatelných cílů zahrnutých do 101 dílčích cílů a 26 výzkumných oblastí). Z výzkumných organizací zřizovaných Ministerstvem kultury dosáhl nejvyššího ohodnocení ještě Národní památkový ústav. Do kategorie „B" bylo dále zařazeno 11 institucí, 4 výzkumné organizace získaly hod-

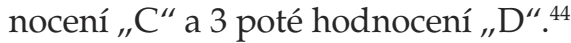

Nově zaváděný pětiletý cyklus hodnocení s sebou přináší ve vztahu k výzkumné organizaci jak pozitivní, tak negativní stránky. Střednědobý interval plánování výzkumu na rozdíl od dosavadního ročního - lze kvitovat v ohledu lepší kontinuity a zhodnocení výsledků, stejně jako finanční fixace výše institucionální podpory. Problematické může být naopak potenciální „,zakonzervování“ vědecko-výzkumné činnosti po stanovené pětileté období díky plánování závazných výzkumných cílů na takto poměrně dlouhou dobu a do jisté míry omezení výzkumu v jiných oblastech, které by se v tomto období mohly objevit. Druhým rizikem je zastupitelnost při personální obměně v Národním muzeu v návaznosti na řešitelské týmy výzkumných cílů a tím vzniklá potenciální absence odborných specialistů v dané problematice. V součinnosti s Metodikou 17+, jež se mj. vyznačuje podporou aplikovaného výzkumu, bude $\mathrm{v}$ následujícím pětiletém období v rámci IP DKRVO Národního muzea věnována pozornost taktéž realizaci aplikovaných výsledků (mezi 40 plánovanými výstupy aplikovaného výzkumu jsou nejčastěji specializované veřejné databáze a funkční vzorky).

\section{Závěr}

Příklad Národního muzea dokazuje, že také muzejní prostředí může nabídnout vhodné zázemí pro kvalitní výzkum srovnatelný s čistě vědeckými institucemi. Realizace vědy na půdě muzejní instituce se však vyznačuje dvěma výraznými specifiky. Zaprvé, pramennou základnou pro základní i aplikovaný výzkum jsou zde sbírky, na něž je v Národním muzeu navázána velká škála souvisejících vědních oborů. Setkáváme se zde tak s ideálním prostředím pro široce pojatý mezioborový výzkum, jenž může zpětně přispět $k$ fungování instituce jako skutečně komplexního organismu. Zadruhé, vědecko-výzkumná aktivita je zde úzce provázána s ostatními činnostmi muzea (např. výstavní a popularizační), což s sebou přináší - viděno perspektivou holistického úhlu pohledu - zcela novou kvalitu v oblasti potenciálu instituce jako celku. Základním stavebním kamenem pro zajištění podmínek rozvoje vědy v Národním muzeu je institucionální podpora. Dále v posledních letech zde dochází díky projektům NAKI k rozvoji aplikovaného výzkumu. Jako výzkumná organizace je Národní muzeum významně ovlivňováno nastavením systému hodnocení výzkumu a vývoje v ČR, přičemž na jeho právě probíhající změny je instituce připravena. Také z výše uvedeného vyplývá, že spojení muzeum a věda (vypůjčíme-li si název Neustupného práce ${ }^{45}$ je nadmíru nosným tématem, které si bezpochyby zaslouží v oblasti muzeologie samostatnou pozornost a hlubší výzkum.

\section{Použité dokumenty}

Definice druhů výsledků, Samostatná příloha č. 4 Metodiky hodnocení výzkumných organizací a programů účelové podpory výzkumu, vývoje a inovací schválené usnesením vlády dne 8 . února 2017 č. 107. [cit. 5. 11. 2019] Dostupné z: https: / / www.vyzkum.cz / FrontClanek.aspx?idsekce $=828970$

Dlouhodobá koncepce rozvoje výzkumné organizace Národní muzeum na léta 2019-2023 (2018). [cit. 5. 11. 2019] Dostupné $\mathrm{z}$ :

https: / / www.vyzkum.cz / FrontClanek.aspx?idsekce $=828970$

Koncepce rozvoje a podpory výzkumu a vývoje v NM 2016-2020 (Příloha č. 1 Směrnice Ǧ̌ č. 10/2016 - Podmínky naplňování Koncepce rozvoje a podpory výzkumu a vývoje v Národním muzeu. [cit. 5. 11. 2019] Dostupné z: https: / / www.nm.cz / muzeum / onas/dulezite-dokumenty

Metodika hodnocení výsledků výzkumných organizací a hodnocení výsledků ukončených programů (platná pro léta 
2013 až 2016). [cit. 5. 11. 2019] Dostupné z: https://www.vyzkum.cz/FrontClanek.aspx?idsekce $=799259$

Metodika hodnocení výzkumných organizací a hodnocení programů účelové podpory výzkumu, vývoje a inovací, schválená Usnesením vlády ČR ze dne 8. února 2017 č. 107 (Metodika 17+). [cit. 5. 11. 2019] Dostupné z:

https:/ / www.vyzkum.cz/FrontClanek.aspx?idsekce $=799796$

Nařízení vlády ze dne 19. ř́jina 2009 o informačním systému výzkumu, experimentálního vývoje a inovací. [cit. 5. 11 . 2019] Dostupné z: https://www.vyzkum.cz $/$ FrontClanek.aspx?idsekce $=68$ 0410

Seznam výzkumných organizací (MŠMT). [cit. 5. 11. 2019] Dostupné z:

http:/ / www.msmt.cz/vyzkum-avyvoj-2/vyzkumne-organizace

Směrnice GǨ č. 10/2016 - Podmínky naplňování Koncepce rozvoje a podpory výzkumu a vývoje v Národním muzeu. [cit. 5. 11. 2019] Dostupné z:

https: / / www.nm.cz/muzeum / onas/dulezite-dokumenty

Souhrnný protokol z hodnocení výzkumných organizací pro poskytování institucionální podpory ze státního rozpočtu na dlouhodobý koncepční rozvoj výzkumných organizací v působnosti Ministerstva kultury na léta 2019-2023, př́loha č. 1. [cit. 5. 11. 2019] Dostupné z: https: / / www.mkcr.cz / vysledkyvstupniho-hodnoceni-vyzkumnych-organizaci-mk-na-zaklade-peer-reviewhodnoceni-dlouhodobe-koncepce-rozv oje-vo-na-leta-2019-2023-1976.html

Struktura oborů OECD (Frascati manual) - převodník 17+. [cit. 5. 11. 2019] Dostupné $\mathrm{z}$ :

https:/ / www.vyzkum.cz/FrontClanek.aspx?idsekce $=799796$

Zákon č. 122/2000 Sb., o ochraně sbírek muzejní povahy a o změně některých dalších zákonů ze dne 7. dubna 2000, ve znění pozdějších předpisů

Zákon č. 130/2002 Sb. ze dne 14. března 2002, o podpoře výzkumu, experimentálního vývoje a inovací $\mathrm{z}$ veřejných prostředků a o změně některých souvisejících zákonů, ve znění pozdějších předpisů
Zřizovací listina Národního muzea (Rozhodnutí ministryně kultury č. 43/2012 ze dne 20. prosince 2012). [cit. 5. 11. 2019] Dostupné z: https: / / www.nm.cz / muzeum / onas/dulezite-dokumenty

\section{Použité informační zdroje}

Centrální evidence sbírek muzejní povahy (CES). [cit. 5. 11. 2019] Dostupné z: http: / / www.cesonline.cz/arlces/cs/index/

Hodnocení výsledků výzkumných organizací v roce 2016: [cit. 5. 11. 2019] Dostupné z:

https: / / www.vyzkum.cz/FrontClanek.aspx?idsekce $=79926$

Hodnocení 17 podle Metodiky 17+, Modul 1 - Hodnocení vybraných výsledků. [cit. 5. 11. 2019] Dostupné z: https://hodnoceni17.rvvi.cz/www/ne biblio

IS VaVaI - Centrální evidence projektů (CEP). [cit. 5. 11. 2019] Dostupné z: https://www.rvvi.cz/cep

IS VaVaI - Centrální evidence záměrů (CEZ). [cit. 5. 11. 2019] Dostupné z: https://www.rvvi.cz/cez

IS VaVaI - Rejstř́ík informací o výsledcích (RIV). [cit. 5. 11. 2019] Dostupné z: https://www.rvvi.cz/riv

\section{Použitá literatura}

NEUSTUPNÝ, Jiří. Muzeum a věda. Muzejní práce, sv. 13. Praha: Národní muzeum, 1968.

NEUSTUPNÝ, Jiří. Otázky dnešnîho muzejnictví. Příspězky k obecné a speciální museologii. Praha: Orbis, 1950.

SKALSKÝ, Gustav a kol. Národní museum 1818-1948. Praha: Národní muzeum, 1949.

SKLENÁř, Karel. Obraz vlasti. Př̌běh Národniho muzea. Praha - Litomyšl: Ladislav Horáček - Paseka, 2001.

WOITSCHOVÁ, Klára a JƯN, Libor. Národní muzeum jako historiografické téma. Časopis Národniho muzea. Řada historická, 2015, roč. 184, č. 1-2, s. 79-92.
44 Viz Souhrnný protokol $z$ hodnocení výzkumných organizací pro poskytování institucionální podpory ze státního rozpočtu na dlouhodobý koncepční rozvoj výzkumných organizací v pưsobnosti Ministerstva kultury na léta 20192023, príloha č. 1. Dostupné z: https://www.mkcr.cz/vysledkyvstupniho-hodnoceni-vyzkumnych-organizaci-mk-na-zaklade-peer-review-hodnocenidlouhodobe-koncepce-rozvoje-vo-na-leta-2019-20231976.html

45 NEUSTUPNÝ, Jiří. Muzeum a věda. Muzejní práce, sv. 13. Praha: Národní muzeum, 1968. 